\title{
Export and total factor productivity of EU new member states
}

\author{
Saša Jakšić ${ }^{1, *}$, Nataša Erjavec ${ }^{1}$ and Boris Cota ${ }^{1}$ \\ 1 University of Zagreb, Faculty of Economics and Business \\ $\operatorname{Trg}$ J. F. Kennedyja 6, 10000 Zagreb, Croatia \\ E-mail: 〈\{sjaksic1, nerjavec, bcota\}@net.efzg.hr〉
}

\begin{abstract}
The common denominator of the European Union's (EU) strategic long-run documents is the role of total factor productivity in fostering future growth and competitiveness. Hence, this article analyses the impact of total factor productivity on export competitiveness in EU new member states (NMS). As opposed to the stagnation of the growth of total factor productivity in the advanced economies, EU NMS exhibited stronger growth that was interrupted due to the 2008 economic and financial crisis. After the crisis, the growth continued but it was not as strong as before. The results of the empirical analysis confirm the vital role of total factor productivity for the export competitiveness of the EU NMS. However, the results also point to the fact that the impact of total factor productivity on export competitiveness is not that beneficial in the countries where the value of total factor productivity has not returned to the pre--crisis level.
\end{abstract}

Keywords: dynamic panel models, EU new members, export competitiveness, total factor productivity

Received: September 29, 2020; accepted: November 16, 2020; available online: December 18, 2020

DOI: $10.17535 /$ crorr.2020.0021

\section{Introduction}

When looking at the strategic documents laying out the future development agenda of the European Union (EU), topics such as competitiveness and productivity are among the most popular ones. These topics are important in academic as well as a policy-making area because they both play an important role in driving economic growth. Competitiveness and productivity are studied individually regarding different measurement concepts. Both concepts are not directly measurable and various indicators are employed to capture competitiveness $[1,25]$ and productivity [5]. Moreover, the relationship between competitiveness and productivity is also a matter of empirical investigation because productivity is usually considered as the main driving force of competitiveness [21].

Regarding productivity, one of the stylized facts that emerged over the last two decades is the stagnating productivity growth of the EU which strongly contributes to diverging income patterns between Europe and US [24]. Nevertheless, the notion of stagnating productivity does not equally apply to the entire EU. EU consists of advanced economies with established market economies as well as post-socialist economies that stemmed from a centrally planned economy environment. That is, the environment in which neither competitiveness nor productivity had the role they have in modern market economies where competitiveness and productivity are placed on the pedestal. Hence, these countries entered the transition process with a low level of productivity and low competitive ability $[8,20]$. Notwithstanding, this kind of setting provided the post-socialist countries with a large catch-up potential. Indeed, these countries exhibited

${ }^{*}$ Corresponding author. 
higher productivity growth rates in comparison to old EU member states. Yet, this growth turned out to be fragile as the 2008 global economic and financial crisis clearly demonstrated.

Therefore, this article investigates the relationship between competitiveness and productivity in post-socialist EU new member states (referred to in the remainder of the text as EU NMS): Bulgaria, Croatia, Czech Republic, Estonia, Hungary, Latvia, Lithuania, Poland, Romania, Slovakia and Slovenia. Malta and Cyprus are not considered in this article as they do not have the centrally-planned economy legacy. As the group of selected EU NMS is itself heterogeneous, the particular emphasis is put in exploring potential differences among the analysed countries. In other words, the question is: Does the total factor productivity have an equal relative impact on competitiveness in all selected EU NMS?

Although there are articles investigating the impact of competitiveness on productivity [15], the impact of productivity on competitiveness is a subject of a small number of empirical research [20]. These studies mostly use firm-level data $[9,16]$ and indicate that productivity is an important determinant of competitiveness. This paper tries to add further insight and reduce the gap in the existing literature by using national level (macroeconomic) data.

Regarding different types of competitiveness, this article focuses on export competitiveness because the poor export performance was one of the key factors that contributed to the disappointing economic performance of the socialist economies [10] and eventually led to the transition towards market-oriented economies.

Productivity is also subject to various measurement concepts. However, Cihák and Fonteyne [7] and Schadler et al. [23] found that the main driver of growth in the EU NMS is the total factor productivity. Total factor productivity (TFP) is the productivity that is not generated by amplified usage of inputs (capital or labour). Instead, it is attributed to intangible factors (for instance, technological progress or organisational innovation) that enable more efficient use of inputs [11]. As such, total factor productivity is not directly measurable and is obtained indirectly as the change in output that is not attributable to changes in inputs [17]. Therefore, total factor productivity is employed as the productivity indicator.

As the concept of competitiveness is a dynamic one, the selected modelling framework has to reflect this. Unlike similar analyses that are mostly based on a single cross-sectional or timeseries data, we employed a panel modelling framework. There are many advantages of panel models over cross-sectional or time-series data. As panel data have more degrees of freedom and sample variability than cross-sectional data, the efficiency of model estimates is improved. Moreover, panel data capture the heterogeneity across cross-sectional units and over time and model the joint dependence [26]. As a result, the complexity of export competitiveness can be analysed better using panel data than a single cross-section or time-series data.

This article adds to the existing literature by introducing further insight into the relationship between total factor productivity and export competitiveness for the selected EU NMS by searching for possible differences in the relative impact of total factor productivity on competitiveness. The analysed period covers almost two decades, i.e. the period from 2000 to 2018. This time frame includes many ups and downs the EU NMS faced: the negotiation and pre-accession period as well as the crisis period.

The main imputs for technological progress is an investment in innovation and knowledge. For that reason, prior to the empirical analysis, the main determinants of total factor productivity in the analysed countries are depicted graphically for a better insight into the background. It is important to note that the literature suggests that the relationship between innovation and total factor productivity is not necessarily a one-to-one relationship. Namely, [19] stresses that rapid technological progress can bring rather little change in total factor productivity. Indeed, in the initial reflections on the first enlargement wave, innovation was not considered the main determinant of productivity growth due to different pattern in the specialisation of the EU NMS [12]. It was considered that large investments in knowledge and innovation would not bring the desired progress. Nevertheless, fifteen years after the initial reflections it is obvious 
that progress in investment in innovation and research and development $(\mathrm{R} \& \mathrm{D})$ still has not 'kicked in'. This lack of investment could be the reason behind the difference in the relative impact of TFP on competitiveness in analysed countries.

The remainder of the paper is structured in the following manner. Section 2 presents an overview of the employed data and methodology applied in the paper. Section 3 presents and discusses the empirical results. Finally, Section 4 summarizes the conclusions of the paper and provides recommendations for future research as well as its limitations.

\section{Data analysis and methodology}

The empirical analysis is performed for a cross-sectional units of selected EU NMS: Bulgaria, Croatia, Czech Republic, Estonia, Hungary, Latvia, Lithuania, Poland, Romania, Slovakia and Slovenia $(N=11)$. Constrained by availability and consistency of data, the research period ranges from 2000 to $2018(T=19)$.

Data on total factor productivity are measured as an index $(2015=100)$ and are obtained from AMECO database (Figure 1).
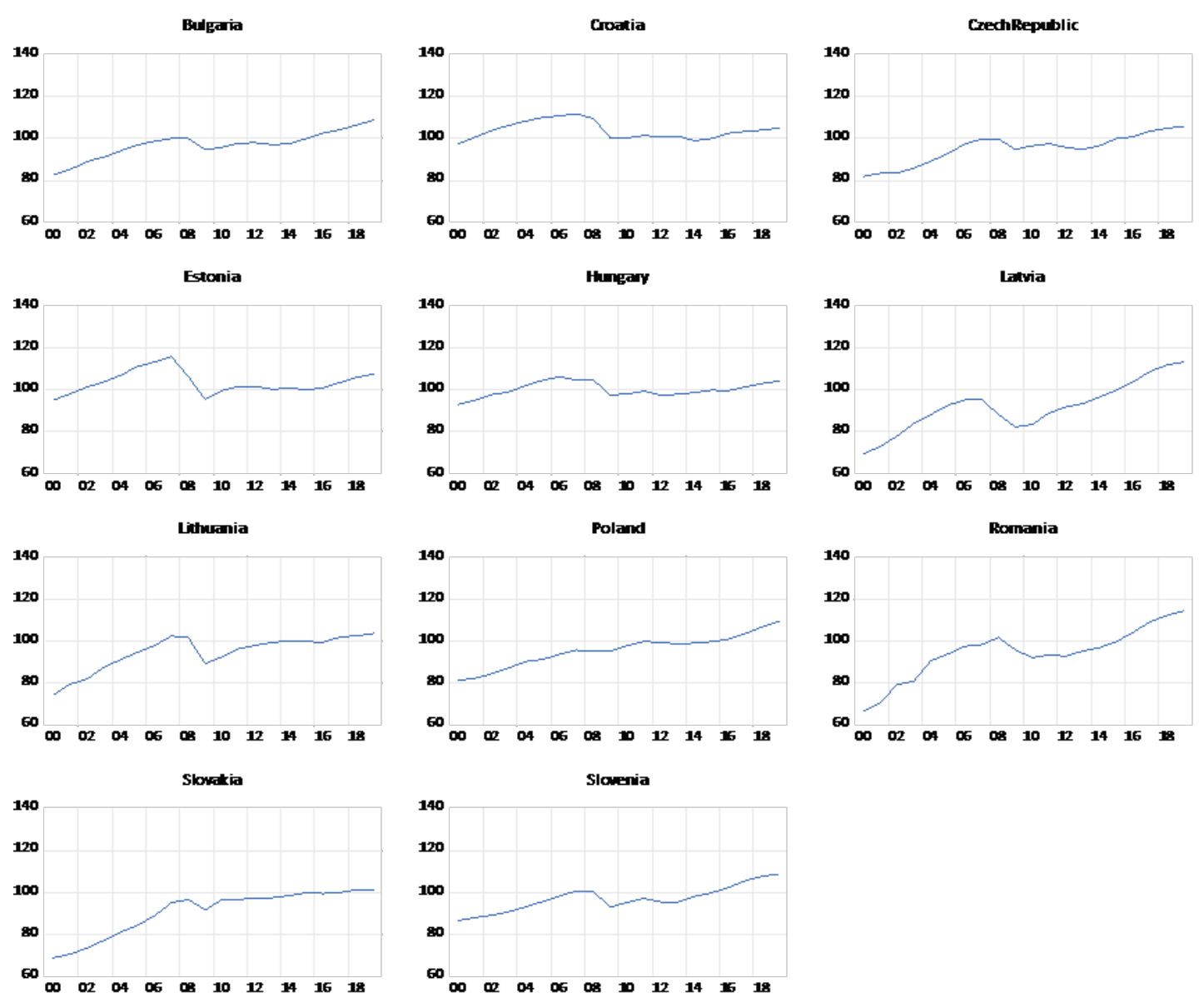

Figure 1: TFP index (2015=100) of the selected EU NMS from 2000 to 2018 
As a dependent variable, the share of the country's export in total world exports (EX) was employed. Independent variables included in the model are total factor productivity (TFP) and two control variables: real effective exchange rate (REER) and unit labour cost (ULC). Dependent variable EX is calculated as the country's share in world exports and represents a measure of a country's export competitiveness. The source of the data is the Direction of Trade Statistics database of the International Monetary Fund.

The real effective exchange rate (REER) is added to the model to assess a country's competitiveness relative to its major competitors in international markets. The data comes from the annual macro-economic database of the European Commission's Directorate-General for Economic and Financial Affairs, AMECO. The indicator is deflated by the price index (total economy) against a panel of 42 countries (EU28 and 14 other industrial countries: Australia, Canada, United States, Japan, Norway, New Zealand, Mexico, Switzerland, Turkey, Russia, China, Brazil, South Korea, and Hong Kong). The real appreciation (a loss of competitiveness) corresponds to an increase in the index.

The second control variable ULC, unit labour cost, measures the average cost of labour per unit of output. Its values are obtained as the ratio of labour costs to labour productivity and come from AMECO database. An improvement of a country's competitive position relative to their trading partners' results in a decline in the relative unit labour cost index.

With a short hiatus due to the 2008 economic and financial crisis, selected EU NMS exhibited growth in total factor productivity in the analysed period which is not surprising. Given the initial condition of these countries at the beginning of the transition process and substantial inefficiencies taken over from the previous, centrally-planned system EU NMS had a large catch-up potential. There was (and still is) plenty of space for managerial improvements and inter-industry resource reallocation [23].

However, if one is to dig deeper, many differences in the dynamics of total factor productivity among the analysed countries would emerge. Table 1 shows the growth rates of total factor productivity of the selected EU NMS from 2000 to 2018 divided into three categories: precrisis period, post-crisis period and the growth rate calculated for the entire analyzed period.

\begin{tabular}{|c|c|c|c|}
\hline $\begin{array}{ll}\text { Period } \\
\text { Country } & \\
\end{array}$ & $\begin{array}{l}\text { prec-crisis } \\
(2000-2007) \\
\end{array}$ & $\begin{array}{l}\text { post-crisis } \\
(2008-2018) \\
\end{array}$ & $\begin{array}{c}\text { entire sample } \\
(2000-2018) \\
\end{array}$ \\
\hline Bulgaria & 20.75 & 6.49 & 28.58 \\
\hline Croatia & 14.70 & -4.95 & 6.80 \\
\hline Estonia & 21.64 & -0.38 & 11.34 \\
\hline Latvia & 37.10 & 26.44 & 60.71 \\
\hline Lithuania & 37.70 & 0.87 & 37.84 \\
\hline Czech Republic & 21.78 & 4.94 & 27.74 \\
\hline Hungary & 12.56 & -1.67 & 10.75 \\
\hline Poland & 17.56 & 12.22 & 31.18 \\
\hline Romania & 46.87 & 10.35 & 67.87 \\
\hline Slovenia & 16.20 & 7.24 & 24.15 \\
\hline Slovakia & 37.92 & 4.93 & 46.95 \\
\hline
\end{tabular}

Table 1: Growth rates of total factor productivity for selected EU NMS from 2000 to 2018

Indeed, in the pre-crisis period, the growth in TFP was impressive in some countries (almost $47 \%$ in Romania and about $38 \%$ in Slovakia, Latvia and Lithuania) while in others it was substantially smaller (Croatia and Hungary). However, in the post-crisis period, some countries swiftly recovered (Latvia) while some countries exhibited negative growth rates (Croatia, Estonia and Hungary). In Lithuania, although the growth rate was slightly above zero, the slowdown in the period after the crisis is also evident. Overall, the growth in total factor 
productivity was largest in Romania and Latvia and lowest in Croatia, Hungary and Estonia.

To test if the relative effects of a unit change in total factor productivity vary in the analyzed countries, the model is expanded with an interaction term $(\mathrm{D} \times \operatorname{lnTFP})$. It is obtained by multiplying the total factor productivity variable and dummy variable $\mathrm{D}$, which takes on value one for the countries where total factor productivity has not returned to the pre-crisis level (Croatia, Estonia, Hungary and Lithuania) and value zero for other countries.

Total factor productivity is usually closely related to innovation. Therefore, for a better insight into the total factor productivity dynamics, the commonly used innovation indicators are illustrated in Figures 2-3.

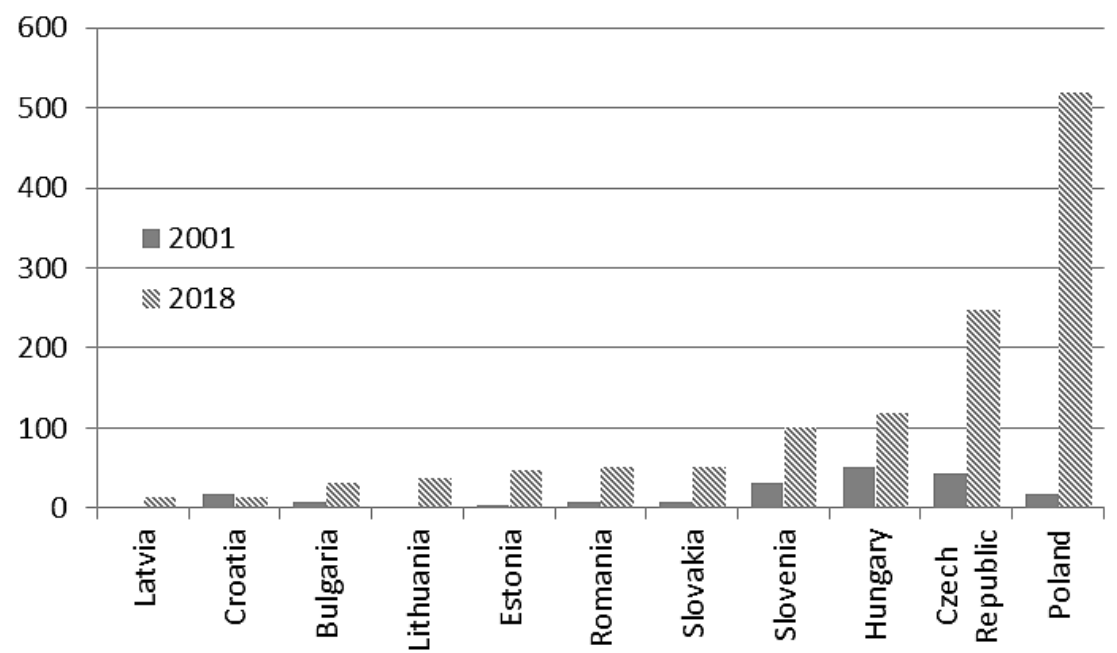

Figure 2: Number of patents of the selected EU NMS, 2001 and 2018

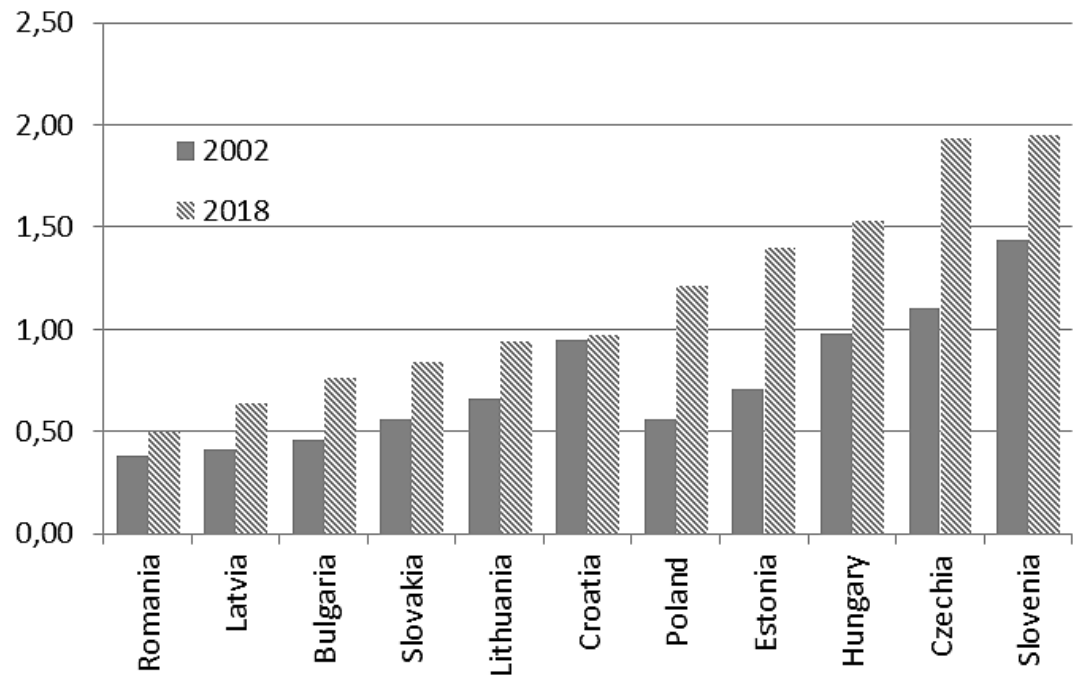

Figure 3: $R \& D$ expenditure (percentage of GDP) of the selected EU NMS, 2002 and 2018 
Apart from Croatia, all other countries increased their R\&D expenditure. Some countries had a substantial increase, like Poland who doubled the share of R\&D expenditures in GDP. Again, these figures are not even close to countries with the highest $R \& D$ intensities: Sweden with $3.32 \%$ and Austria with $3.17 \%$. Therefore, it is evident that selected EU NMS are lagging behind advanced EU economies regarding innovation indicators. Moreover, it is also clear that there are striking differences among the selected countries and this will be further investigated in the empirical analysis.

All variables employed in the empirical analysis are log-transformed. Additionally, to control for the impact of the 2008 global economic and financial crisis, a dummy variable Crisis is added to the model.

The dynamic panel model with one lagged dependent variable is selected as an appropriate modelling specification considering the dynamic nature of the analysed variables and contemporaneous correlations conditional on the past $[2,3]$.

$$
y_{i t}=X_{i t}^{\prime} \beta+\gamma \cdot y_{i t-1}+\delta \cdot \text { Crisis }_{i t}+\alpha_{i}+\varepsilon_{i t} \quad i=1,2, \ldots, N \quad T=2,3, \ldots, T,
$$

where $y_{i t}$ is a dependent variable, $X_{i t}$ is the matrix of independent variables, $\alpha_{i}$ is the (unobserved) individual effect, and $\varepsilon_{i t}$ is the error (idiosyncratic) term with $E\left(\varepsilon_{i t}\right)=0$ and $E\left(\varepsilon_{i t} \varepsilon_{j s}\right)=\sigma_{\varepsilon}^{2}$ if $j=i$ and $t=S$ and $E\left(\varepsilon_{i t} \varepsilon_{j s}\right)=0$ otherwise. Dummy variable Crisis captures the potential impact of the 2008 global economic and financial crisis.

The model in equation (1) is suitable in cases when unobservable factors affect both the dependent variable and explanatory variables resulting in a correlation between some explanatory variables and lagged dependent variable, which is likely to be the case in our analysis. It captures the dynamic interaction between variables and deals with unobserved heterogeneity across selected countries. As a result, parameter estimates are more efficient compared to static panel model $[3,6]$.

\section{Empirical results}

The results of the estimated model (1) are presented in Table 2. The Windmeijer-corrected standard errors (robust to heteroskedasticity and arbitrary patterns of autocorrelation) were applied [27].

\begin{tabular}{|l|ccrc|}
\hline Variable & Coefficient & Robust s.e. & t-statistic & p-value \\
\hline \hline EX $_{i t-1}$ & $0.584305^{* * *}$ & 0.1218331 & 4.80 & 0.001 \\
$\operatorname{lnREER}_{i t}$ & -0.015101 & 0.1595257 & -0.09 & 0.926 \\
$\operatorname{lnULC}_{i t}$ & 0.148839 & 0.1119456 & 1.33 & 0.211 \\
$\operatorname{lnTFP}_{i t}$ & $1.212760^{* *}$ & 0.4941675 & 2.45 & 0.032 \\
D $^{*} \operatorname{lnTFP}_{i t}$ & $-1.538040^{* *}$ & 0.5518731 & -2.79 & 0.018 \\
Crisis $_{i t}$ & -0.019566 & 0.0362612 & -0.54 & 0.600 \\
\hline
\end{tabular}

Table 2: Dynamic panel model estimation results with export $E X_{i t}$ as dependent variable Note: ${ }^{* *},{ }^{* *},{ }^{*}$ indicate significance at the $1 \%, 5 \%$ and $10 \%$ levels, respectively.

The results of performed diagnostic tests [22] are reported in Table 3. The $F$-statistic $(F=520.16, p-$ value $=0.000)$ confirms the suitability of the dynamic panel model specification. The parameter estimators are consistent as there is no second-order serial correlation for the idiosyncratic errors of the first-differenced equation $(p-$ value $=0.456)$. The first-order serial correlation $(p-$ value $=0.030)$, due to the lagged dependent term, is expected. Hansen test of over-identifying restrictions $(p-$ value $=0.899)$ indicates that the instruments are exogenous, 
which is the crucial assumption for the validity of the model. Moreover, the Hansen test excluding a group $(p-$ value $=0.730)$ does not reject the null that the model with additional instruments is correctly specified. Thus, all specification tests support the model adequacy.

\begin{tabular}{|l|rr|}
\hline \multicolumn{1}{|c|}{ Test } & Statistic & p-value \\
\hline \hline Arellano-Bond test for AR(1) in first differences & $z=-2.17$ & 0.030 \\
Arellano-Bond test for AR(2) in first differences & $z=-0.75$ & 0.456 \\
F-test & $F=520.16$ & 0.000 \\
Hansen test of overid. restrictions & $\chi^{2}(14)=7.82$ & 0.899 \\
Hansen test excluding group & $\chi^{2}(11)=7.82$ & 0.730 \\
Difference (null H = exogenous) & $\chi^{2}(3)=0.000$ & 1.000 \\
\hline Number of observations & \multicolumn{3}{|}{186} \\
Number of instruments & \multicolumn{3}{|}{} \\
Number of groups & \multicolumn{2}{|c}{} \\
\hline
\end{tabular}

Table 3: Model diagnostics

Looking at the results of the estimated model (Table 2) as expected, the lagged dependent variable is statistically significant with a positive sign indicating that export competitiveness is heavily determined by its past values. The crisis dummy variable turned out to be statistically insignificant as the crisis affected both the countries' exports (the numerator of the dependent variable EX) and the world exports (denominator of EX).

Total factor productivity is statistically significant at the $5 \%$ level and has the expected positive sign. This means that the increase of total factor productivity, on average, leads to an improvement in export competitiveness in selected EU NMS.

Both control variables (the real effective exchange rate and unit labour cost) are not statistically significant. This result indicates that, due to the process of globalization, a further increase in export competitiveness is primarily associated with the total factor productivity.

The interaction term is statistically significant and negative. Therefore, the increase in total factor productivity, on average, increases export competitiveness in EU NMS. However, the relative impact is smaller in countries with negative (or weaker) growth in total factor productivity in the period following the 2008 global economic and financial crisis. [9] found that the productivity-exports nexus is affected by the ability of an economy to efficiently allocate its resources, this finding indicates possible allocative inefficiency in Croatia, Estonia, Hungary and Lithuania.

Corruption could be one of the factors that contribute to the inefficiency in Croatia and Hungary as these countries are at the bottom of the list of the Corruption perceptions index (Figure 4). To have a better picture on where do exactly these countries stand, highest-ranked Denmark has a score 88 (higher index value corresponds to less severe corruption problems) while Croatia and Hungary are ranked 60th and 64th, respectively. 


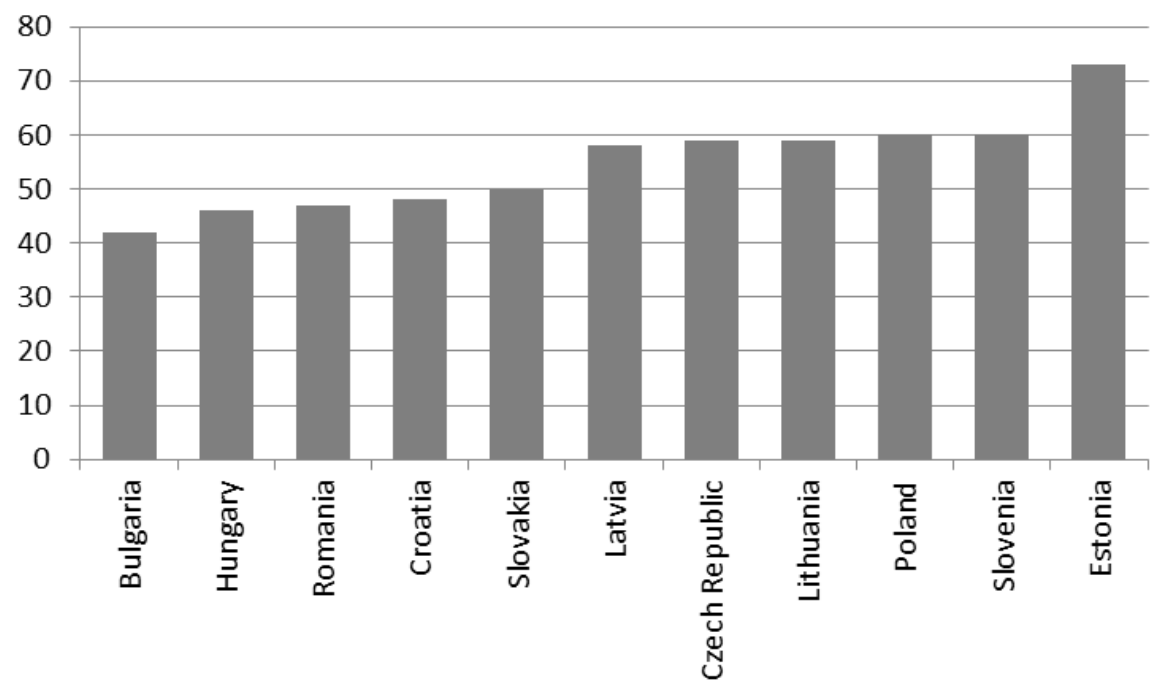

Figure 4: Corruption perceptions index 2018

In the study [14] authors found that corruption influences total factor productivity both directly (constraining productive activities) and indirectly (by diverting resources to less productive units). And yet, in Estonia and Lithuania, which are countries least 'infested' with the corruption of all the analysed countries, the relationship between export competitiveness and total factor productivity is also unfavourable. One possible factor that disables the efficient allocation of resources in Estonia and Lithuania may lie in the structure of R\&D expenditure which is presented in Table 4.

\begin{tabular}{|l|ll|ll|lc|}
\hline & \multicolumn{2}{|l|}{ Business enterprise sector } & \multicolumn{2}{|c|}{ Government sector } & \multicolumn{2}{c|}{ Higher education sector } \\
& 2002 & 2018 & 2002 & 2018 & 2002 & 2018 \\
\hline \hline EU & 63.8 & 66.7 & 13.0 & 10.7 & 22.4 & 21.8 \\
Bulgaria & 18.5 & 71.9 & 71.4 & 22.1 & 10.0 & 5.4 \\
Czech Republic & 61.1 & 61.9 & 23.0 & 16.4 & 15.6 & 21.5 \\
Estonia & 30.7 & 42.3 & 17.0 & 11.4 & 47.9 & 44.5 \\
Croatia & 42.7 & 48.0 & 22.2 & 19.9 & 35.1 & 32.0 \\
Latvia & 40.9 & 24.9 & 19.0 & 22.8 & 40.1 & 52.4 \\
Lithuania & 16.9 & 41.8 & 33.4 & 22.2 & 49.8 & 35.9 \\
Hungary & 35.5 & 75.6 & 32.9 & 10.9 & 25.2 & 12.7 \\
Poland & 20.3 & 66.1 & 45.5 & 1.9 & 33.9 & 31.7 \\
Romania & 60.3 & 59.3 & 24.2 & 30.6 & 15.6 & 9.8 \\
Slovenia & 59.7 & 74.2 & 23.1 & 13.6 & 15.5 & 11.9 \\
Slovakia & 64.3 & 54.1 & 26.6 & 21.2 & 9.1 & 24.3 \\
\hline
\end{tabular}

Table 4: $R \& D$ expenditure by sector of performance (\% of total), 2002 and 2018

In the post-crisis period, government spending shifted from investment towards current expenditure [13]. This is why the share of the government sector in R\&D expenditure decreased in most of the countries. The biggest decrease was in Poland where the share dropped from $45.5 \%$ in 2002 to only $1.9 \%$ in 2018 . In addition to a decrease in government spending, $\mathrm{R} \& \mathrm{D}$ intensity (measured in euros per inhabitant) decreased as well (Figure 5). 


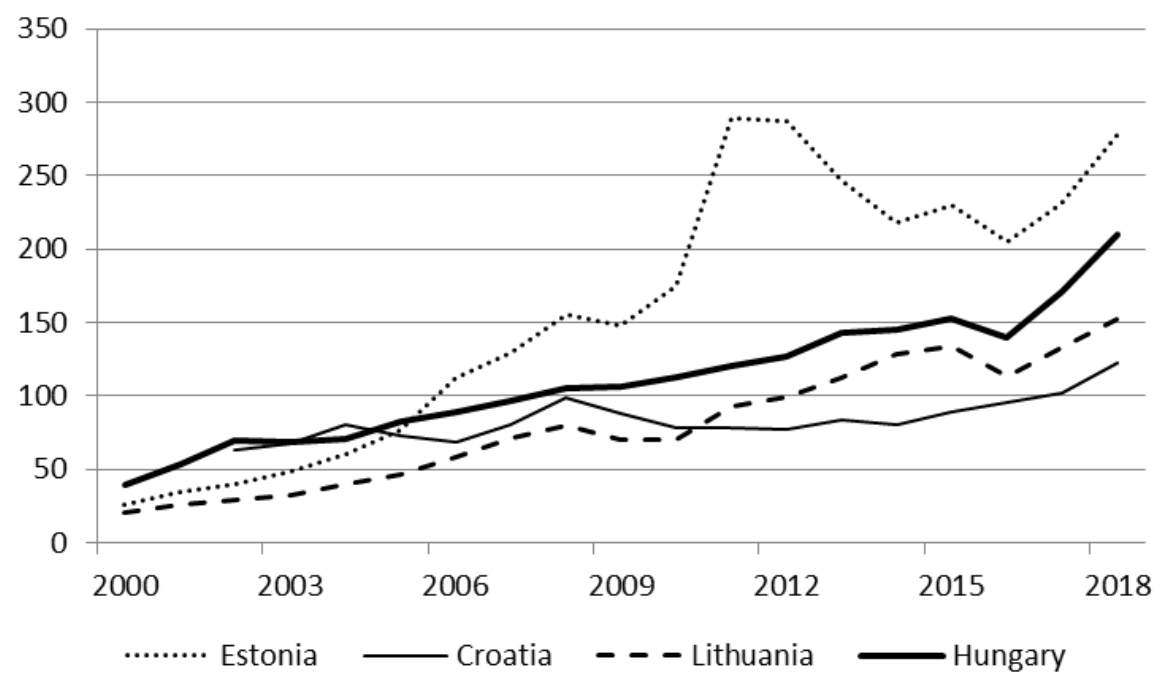

Figure 5: R\&D expenditure (in euro per inhabitant), 2000 to 2018

Figure 5 indicates that in the aftermath of the crisis the countries lost the momentum and they were unable to keep the pace of the previous growth in R\&D investment. This consequently reflected the total factor productivity and, ultimately, export competitiveness. Previous high growth rates did not mean much, because in catching-up economies innovation is more oriented towards equipment rather than R\&D [18].

Therefore, the environment for entrepreneurship and innovation in the analyzed countries is still viable for improvement and this would help in channelling the resources towards a more efficient use. While some of the countries seem to be on the right track, the future definitely looks gloomy for Croatia. One word comes to mind when looking at Croatia's figures: stagnation. Some of the indicators improved only slightly, some are virtually the same and some indicators have even gone from bad to worse. In a dynamic setting, stagnation is the worst possible scenario. The only way forward is in improving the setting for innovation and efficient allocation of resources through the implementation of structural reforms and tackling with corruption.

\section{Conclusion}

Competitiveness and productivity are at the top of the lists of strategic documents laying out the future development agenda of the European Union. Although the role of productivity in fostering competitiveness is straightforward this article provides insight into the relationship between productivity and competitiveness for a group of countries that originate from a centrally-planned economy environment. These countries entered the transition process with a low level of productivity and low competitive ability. To assess the relationship between export competitiveness and total factor productivity a dynamic panel data model with one lagged dependent variable was estimated. The obtained results show that for selected EU NMS export competitiveness significantly depends on its past values and total factor productivity. The increase in total factor productivity, on average, increases export competitiveness. However, the relative impact is smaller in countries with negative growth in total factor productivity following the 2008 global economic and financial crisis. The results suggest that the productivity-exports nexus is affected by the ability of an economy to allocate its resources efficiently. 
However, on the wings of a large catch-up potential, while other advanced EU economies recorded stagnating productivity growth rates, EU NMS countries had impressive productivity growth rates. Eventually, the impressive growth rates came to a halt with the emergence of the 2008 global economic and financial crisis. Swift recovery of part of the EU NMS demonstrated the robustness of their productivity growth. On the other hand, the inability of the remaining countries to recover productivity growth rate to the pre-crisis level proved the fragility of their productivity growth. These countries should persist along the lines of implementing structural reforms, tackling corruption and investing in innovation.

With the year 2020 bringing new challenges that the modern economies have never seen before, the possibility to pursue growth recovery policy recommendations will, to a large extent, depend on the ability of the economies to cope with them. This could be a chance for the policymakers to prioritise the structural reforms that are continuously postponed. On the other hand, the inability to overcome the accumulated as well as new difficulties would probably give rise to further stagnation or even deterioration.

The main limitation of the study is that it does not answer how total factor productivity is affected by various factors and why differences in productivity exist across countries. Further research needs to find obstacles that affect the main drivers of total factor productivity in some countries. It could be interesting to see how to export diversification contributes to export growth and the impact of productivity growth.

\section{Acknowledgements}

This work has been fully supported by Croatian Science Foundation under the project IP-201409-5476.

\section{References}

[1] Aiginger, K., Bärenthaler-Sieber, S. and Vogel, J. (2013). Competitiveness under new perspectives. Welfare Wealth Work for Europe Working Paper, 44, 1-86. doi: 10.13140/RG.2.1.1003.1525

[2] Alvarez, J. and Arellano, M. (2003). The time--series and cross-section asymptotics of dynamic panel data estimators. Econometrica, 71(4), 1121-1159. doi: 10.1111/1468-0262.00441

[3] Arellano, M. and Bover, O. (1995). Another look at the instrumental variable estimation of errorcomponents models. Journal of Econometrics, 68(1), 29-51. doi: 10.1016/0304-4076(94)01642-d

[4] Baltagi, B. H. (2013). Econometric Analysis of Panel Data, 5th Edition. Chichester: Wiley.

[5] Baumol W. J. and Wolff E. N. (1989). Three fundamental productivity concepts: Principles and measurement. In Feiwel G. R. (Eds.) Joan Robinson and Modern Economic Theory (pp. 638-659). London: Palgrave Macmillan. doi: 10.1007/978-1-349-08633-7_22

[6] Blundell, R. and Bond, S. (1998). Initial conditions and moment restrictions in dynamic panel data models. Journal of Econometrics, 87(1), 115-143. doi: 10.1016/s0304-4076(98)00009-8

[7] Cihák, M. M. and Fonteyne, M. W. (2009). Five years after: European Union membership and macro-financial stability in the new member states. International Monetary Fund Working Papers, 9(68), 1-67. doi: 10.5089/9781451872156.001

[8] Corbo, V. Coricelli, F. and Bossak, J. (1992). Reforming Central and Eastern European economies: Initial results and challenges. Choice Reviews Online, 29(6), 29-5235. doi: 10.5860/choice.29-5235

[9] di Mauro, F., Mottironi, B., Ottaviano, G. I. and Zona-Mattioli, A. (2018). Living with lower productivity growth: Impact on exports. Peterson Institute for International Economics Working Paper, 18(10), 1-18. doi: 10.2139/ssrn.3247716

[10] Drabek, Z. and Olechowski, A. (1989). Price and quality competitiveness of socialist countries' exports. Policy, Planning and Research Department Working Paper Series, 317, 1-22. https: //ideas.repec.org/p/wbk/wbrwps/317.html

[11] European Commission. (2008). Competitiveness and economic reforms. European competitiveness report 2007, 1-185. https://op.europa.eu/en/publication-detail/-/publication/ 231e7f69-4cb9-4bbb-aef3-eb965d255281 
[12] European Commission. (2004). Catching-up, growth and convergence of the new member states. The EU economy: 2004 review, 87-163. https://ec.europa.eu/economy_finance/ publications/pages/publication7718_en.pdf

[13] European Investment Bank. (2017). From Recovery to Sustainable Growth. Investment Report 2017/2018, 1-388. https://www.eib.org/attachments/efs/economic_investment_report_ 2017_en.pdf

[14] Giordano, C. and Lopez-Garcia, P. (2018). Is corruption efficiency-enhancing? A case study of the Central and Eastern European region. The European Journal of Comparative Economics, 15(1), 119-164. doi: 10.25428/1824-2979/201801-119-164

[15] Kegels, C. and van der Linden, J. (2011). Competitiveness, productivity, competition and structural reforms: The Belgian case. Reflets et perspectives de la vie économique, L(3), 27-51. doi: $10.3917 /$ rpve.503.0027

[16] Laureti, T. and Viviani, A. (2011). Competitiveness and productivity: A case study of Italian firms. Applied Economics, 43(20), 2615-2625. doi: 10.1080/00036840903357439

[17] Lopez-Rodriguez, J. and Martinez-Lopez, D. (2017). Looking beyond the R\&D effects on innovation: the contribution of non-R\&D activities to total factor productivity growth in the EU. Structural Change and Economic Dynamics, 40, 37-45. doi: 10.1016/j.strueco.2016.11.002

[18] Masso, J. and Vahter, P. (2008). Technological Innovation and Productivity in Post-Transition Estonia: Econometric Evidence from Innovation Surveys. European Journal of Development Research, 20(2), 240-261. doi: 10.1080/09578810802060751

[19] Neary, J. P. (2002). Foreign competition and wage inequality. Review of International Economics, 10(4), 680-693. doi: 10.1111/1467-9396.00358

[20] Ofer, G. (1992). Productivity, competitiveness and the socialist system. In Hickmann, B. (Eds.) International Productivity and Competitiveness (pp. 97-133). New York: Oxford University Press.

[21] Porter, M. E. (1990). The Competitive Advantage of Nations. Harvard Business Review. https: //hbr.org/1990/03/the-competitive-advantage-of-nations [Accessed 11/07/20].

[22] Roodman, D. (2009). A note on the theme of too many instruments. Oxford Bulletin of Economics and Statistics, 71(1), 135-158. doi: 10.1111/j.1468-0084.2008.00542.x

[23] Schadler, S., Mody, A., Abiad, A. and Leigh, D. (2006). Growth in the Central and Eastern European countries of the European Union. International Monetary Fund Occasional Papers, 252, 1-55. https://www.imf .org/external/pubs/nft/op/252/op252.pdf

[24] Schwab, K. (2014). The Europe 2020 Competitiveness Report. World Economic Forum. http: //www3.weforum.org/docs/CSI/2012/Europe2020_Competitiveness_Report_2012.pdf

[25] Siudek, T. and Zawojska, A. (2014). Competitiveness in the economic concepts, theories and empirical research. Oeconomia - Acta Scientiarum Polonorum, 13(1), 91-108. http://www. oeconomia. actapol.net/pub/13_1_91.pdf

[26] Škrabić Perić, B. (2019). Do the most frequently used dynamic panel data estimators have the best performance in a small sample? A Monte Carlo comparison. Croatian Operational Research Review, 10(1), 45-55. doi: 10.17535/crorr.2019.0005

[27] Windmeijer, F. (2005). A finite sample correction for the variance of linear efficient two-step GMM estimators. Journal of Econometrics, 126(1), 25-51. doi: 10.1016/j.jeconom.2004.02.005 